\title{
Sparkol VideoScribe Application for Instruction
}

\author{
Muhammad Kristiawan ${ }^{1, *}$ and Nur Aminudin ${ }^{2}$
}

\author{
${ }^{1}$ Science of Education, University of Bengkulu, Bengkulu, Indonesia \\ ${ }^{2}$ Science of Computer, University of Aisyah Pringsewu, Pringsewu, Indonesia \\ *Corresponding author. Email: muhammadkristiawan@unib.ac.id
}

\begin{abstract}
Different types of technical applications were not included in the instruction at the Faculty of Education, University of Bengkulu. Every teaching activity is just making a paper and a daily presentation of PowerPoint, then discussing it together. This activity appears to be monotonous. This research was performed using the Sparkol Videoscribe program, which was then uploaded to YouTube and discussed in the Google classroom to optimize learning. The students are taught how to make and upload the videos to YouTube and then respond to what has been done. We asked the students to provide a feedback on the Google form to see the effect of this analysis. As a result, the students were very happy and concluded that this technique could optimize the learning, especially based on technology. This study presents Sparkol Videoscribe which can easier teachers to pass on the knowledge and increase motivation and can be an alternative media that can increase student interest in learning.
\end{abstract}

Keywords: Sparkol Videoscribe, YouTube, Google Classroom, Google Form.

\section{INTRODUCTION}

The age of the Industrial Revolution 4.0 presents every nation with new challenges. In a very competitive global world, we should thrive [1]. In many fields, the use of technology has the potential to enable individuals and societies to build opportunities to meet the challenges of this period, a renewal that needs future employees' ability to adapt and improve the world [2].

Globalization past illustrates that any evolving age has its own heart [3]. Educational tools that can and follow technological advances are required in this very fast-paced era of Revolution 4.0, so that the goals anticipated by educational organizations can be achieved, especially in improving school quality [4]; [5].

In the age of the industrial revolution 4.0 attempts to enhance the quality of progress lie in the essential role of educators and students in educational institutions. In the creation of organizations ready to face the industrial revolution 4.0., the courses taught at the faculty of education play an important role. The urgent need to continue learning and advanced digital technology needs a new approach to changing global circumstances in the age of the industrial revolution 4.0, such as growing productivity requirements [6].
The concern that has been posed and is a priority for resolution at this moment is that it has not been optimal to learn about leadership growth and decision making and educational theory. This topic is related to the success of the researcher, since the researcher received the Leadership Development and Decision-Making Courses and Educational Philosophy this semester. This issue was caused by a lack of awareness about creating Sparkol VideoScribe based on information technology while studying at the Faculty of Education, University of Bengkulu. This has a learning effect that is not interesting and does not inspire students to comprehend the content.

Not only because of the results, it is also an initiative of researchers to prepare Sparkol VideoScribe-based teaching materials so that the lecturers are also willing to apply the method established by the author. The preparation of this teaching material is a feature of civil servants [7] Enforcing Policy, since the policy of the Dean of the Faculty of Education, University of Bengkulu, is information technology-based learning. In addition, the preparation of this teaching material is also an attempt to share information, as Indonesia's potential human resources are students. This study was carried out with the goal of carrying out a creative, innovative and contextual learning process; preparing, implementing the learning process and reviewing and evaluating learning outcomes; enhancing and 
developing academic qualifications and skills on an ongoing basis in line with the advancement of science, technology and the arts; the realization of educational research in the context of ground-breaking, original and tested experimental work; and the introduction and distribution of educational and research products through community service [8]; [9]; [10]; [11]; [12].

\section{METHODS}

This research was done from February to April 2020 with 88 respondents with $73.2 \%$ female respondents as shown in Figure 1.

\section{Table 1. Indicator of Research Methods}

\begin{tabular}{|c|l|}
\hline No & The Activities \\
\hline 1 & $\begin{array}{l}\text { Collection of information about making } \\
\text { Sparkol Videoscribe-based teaching materials }\end{array}$ \\
\hline 2 & Seeking Tutor \\
\hline 3 & Compiling Materials with Peer Teaching \\
\hline 4 & $\begin{array}{l}\text { Review and Modification Sparkol Videoscribe- } \\
\text { based teaching materials }\end{array}$ \\
\hline 5 & $\begin{array}{l}\text { Finalization of Sparkol Videoscribe-based } \\
\text { Teaching Materials }\end{array}$ \\
\hline 6 & Trial of Teaching Materials to Students \\
\hline
\end{tabular}

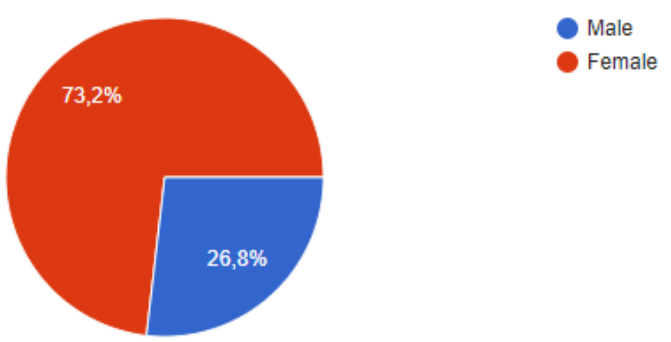

\section{Figure 1. Sex of Respondents}

In this research, we did a lot of phases. Collecting details about making teaching materials based on Sparkol VideoScribe, explaining the phases of the tasks, calling the supervisor directly and making an appointment for a meeting; and talking directly to mentors and direct supervisors Prof. Dr. Wachidi, M.Pd, the plan to make teaching materials based on Sparkol VideoScribe. This supports the mission of University of Bengkulu, the Faculty of Education and Teacher Training to coordinate the education and learning in a professional and responsible manner. Meanwhile, the impact analysis is that if we do not check with the direct supervisor about training on Sparkol VideoScribe-based teaching materials, then we will not get feedback on what job procedures we should do [13].

The operation here was to contact Mr. Eko Risdianto, M.Sc., after searching for a tutor. In order to meet local, national and international education needs, this was done to coordinate and improve competitive and efficient programs. Then, by direct collaboration with tutors, the strengthening of organizational values in this operation demonstrates the presence of responsibility to operate with standardized principles in a calculated way and achieve accountable production and a culture of organizational quality. The effect analysis, meanwhile, is that if we don't search for a tutor and don't coordinate with the tutor, I'm going to find it hard to build Sparkol VideoScribe-based teaching materials [14].

Prof. Dr. Syukri Hamzah, M.Si, explains the phases of the tasks by compiling material with peer teaching. To compile teaching materials to be distributed through Sparkol VideoScribe, as peer teaching. This mission is to obtain from the ideas of foreign scientists the new research materials and books on Leadership and Decision Making and Philosophy Education. The material ideas communicated to students would be unified. The effect review, meanwhile, is that if I don't compile the material with peer teaching, then I would be authoritarian and not impartial in deciding teaching materials for Sparkol VideoScribe.

Examination and revision of VideoScribe Leadership and Decision Making and Education Materials Theory, then. According to feedback from mentors and peer teaching, the summary of the phases of the exercise is to make a review form that will be given to mentors and peer teaching, provide Sparkol VideoScribe teaching material files to mentors and peer teaching, collect the completed review forms, and revise teaching materials. We still uphold integrity and objectivity through the process of updating and revising teaching materials for mentors and peer teaching. The impact analysis, meanwhile, is that if we do not review and update the teaching materials with mentors and peer teaching, then we will not know what is wrong with the teaching materials we have made. Then the result of this activity also enhanced the materials we produced for teaching.

Finalization of Sparkol VideoScribe-based leadership and decision-making and educational theory content is described here. The definition of the operation stages is to perfect the Sparkol VideoScribe-based materials according to feedback and ready to use. This operation results in the $\mathrm{OK}$ file being ready to be checked. It means preserving the importance of professionalism, objectivity, trustworthiness, efficiency and quality culture with the finalisation of teaching materials. Meanwhile, if we do not complete the Sparkol VideoScribe-based Leadership and Decision Making and Philosophy of Education materials, then we are not accountable and do not help realize the Universitas Bengkulu educational faculty 's vision.

The last is the student teaching materials trial. The definition of the activity phases is to look at the lecture schedule, compile a questionnaire on the student response, and evaluate the student questionnaire 
outcomes. Testing teaching materials means fulfilling the task of the University of Bengkulu Faculty of Education to coordinate and develop competitive and effective programs to meet local, national and foreign educational needs. Maintaining the importance of professionalism, objectivity, commitment to principles, accountability, trustworthiness, reliability and culture of quality implies the presence of research. If we don't try the Sparkol VideoScribe-based Leadership and Decision
Making and Philosophy of Education materials, then I am not responsible and not competent.

\section{RESULTS AND DISCUSSION}

When conducting the research, there are many challenges that occur. In addition to barriers, there are also expectations that can be made to address these barriers. In the table 1 , the limitations and anticipation of the challenges faced can be seen.

Table 2. Barriers and Anticipation

\begin{tabular}{|c|c|c|c|c|}
\hline No & Activity & Barriers & Anticipation & \\
\hline 1 & $\begin{array}{l}\text { Collection of } \\
\text { information } \\
\text { about the } \\
\text { making of } \\
\text { Sparkol } \\
\text { VideoScribe } \\
\text { based } \\
\text { teaching } \\
\text { materials }\end{array}$ & $\begin{array}{l}\text { Bosses have } \\
\text { quite a solid } \\
\text { agenda at } \\
\text { work so it's } \\
\text { a bit } \\
\text { difficult to } \\
\text { coordinate } \\
\text { actualization } \\
\text { plans. }\end{array}$ & $\begin{array}{l}\text { The boss } \\
\text { immediately } \\
\text { took the time } \\
\text { to give } \\
\text { directions } \\
\text { even though } \\
\text { he was not in } \\
\text { his office. }\end{array}$ & $\begin{array}{l}\text { https://www.youtube.com/watch?v=9TD6DiqbcYk } \\
\text { https://www.youtube.com/watch?v=HfrD7QoYWSU }\end{array}$ \\
\hline 2 & $\begin{array}{l}\text { Looking for } \\
\text { Tutor }\end{array}$ & $\begin{array}{l}\text { Mr. Eko } \\
\text { Risdianto, } \\
\text { M.Sc. have } \\
\text { a pretty } \\
\text { solid agenda } \\
\text { at work } \\
\text { during the } \\
\text { day }\end{array}$ & $\begin{array}{l}\text { Consultation } \\
\text { at night or on } \\
\text { holidays }\end{array}$ & $\begin{array}{l}\text { https://www.youtube.com/watch?v=qRIQJBkKJYE } \\
\text { https://www.youtube.com/watch?v=anL753KBzP0 } \\
\text { https://www.youtube.com/watch?v=qEp19ExqZGE }\end{array}$ \\
\hline 3 & $\begin{array}{l}\text { Compiling } \\
\text { Material } \\
\text { with Peer } \\
\text { Teaching }\end{array}$ & $\begin{array}{l}\text { Prof. Dr. } \\
\text { Syukri } \\
\text { Hamzah, } \\
\text { M.Si. often } \\
\text { not on } \\
\text { campus due } \\
\text { to busy } \\
\text { activities off } \\
\text { campus. } \\
\text { Then it was } \\
\text { difficult to } \\
\text { understand } \\
\text { the } \\
\text { references } \\
\text { in English. }\end{array}$ & $\begin{array}{l}\text { Communicate } \\
\text { outside the } \\
\text { campus in } \\
\text { accordance } \\
\text { with the } \\
\text { agreement } \\
\text { with him. it } \\
\text { takes a lot of } \\
\text { time to } \\
\text { understand } \\
\text { English } \\
\text { references. }\end{array}$ & \\
\hline 4 & $\begin{array}{l}\text { Review and } \\
\text { Revision of } \\
\text { Sparkol } \\
\text { VideoScribe- } \\
\text { Based } \\
\text { Teaching } \\
\text { Materials }\end{array}$ & $\begin{array}{l}\text { Availability } \\
\text { of time for } \\
\text { mentors and } \\
\text { peer } \\
\text { teaching due } \\
\text { to busy } \\
\text { activities. }\end{array}$ & $\begin{array}{l}\text { Use free time } \\
\text { for mentors } \\
\text { and peer } \\
\text { teaching to } \\
\text { conduct } \\
\text { reviews. }\end{array}$ & https://forms.gle/J1cxAaP7od4f9ji27 \\
\hline 5 & $\begin{array}{l}\text { Finalization } \\
\text { of Sparkol } \\
\text { VideoScribe } \\
\text { Based } \\
\text { Teaching } \\
\text { Materials }\end{array}$ & $\begin{array}{l}\text { The time } \\
\text { given is } \\
\text { very limited. }\end{array}$ & $\begin{array}{l}\text { Doing } \\
\text { overtime. }\end{array}$ & \\
\hline 6 & $\begin{array}{l}\text { Trial of } \\
\text { Teaching } \\
\text { Materials to }\end{array}$ & $\begin{array}{l}\text { Can only be } \\
\text { done while } \\
\text { studying. }\end{array}$ & $\begin{array}{l}\text { Ask for peer } \\
\text { teaching } \\
\text { assistance to }\end{array}$ & $\begin{array}{l}\text { https://www.youtube.com/watch?v=WM7K2qzH6q4 } \\
\text { https://www.youtube.com/watch?v=Is6KCYKOKvY }\end{array}$ \\
\hline
\end{tabular}




\begin{tabular}{|c|c|c|}
\hline Students & $\begin{array}{l}\text { be able to do } \\
\text { a trial. }\end{array}$ & $\begin{array}{l}\text { https://www.youtube.com/watch?v=75FjnDhDgNA } \\
\text { https://www.youtube.com/watch?v=wJF4y308a_M } \\
\text { https://www.youtube.com/watch?v=PXekhLhnask } \\
\text { https://www.youtube.com/watch?v=kIELH5_11Ss\&t=128s } \\
\text { https://www.youtube.com/watch?v=hL5Sav3jrzM } \\
\text { https://www.youtube.com/watch?v=MpT9x38L5hY } \\
\text { https://www.youtube.com/watch?v=CUQXAhLrFJQ\&feature=youtu.be } \\
\text { https://www.youtube.com/watch?v=U2iA_WzZAuQ\&feature=youtu.be } \\
\text { https://www.youtube.com/watch?v=h-NJLjQY41o\&feature=youtu.be } \\
\text { https://www.youtube.com/watch?v=qqmPyGkEbms\&feature=youtu.be } \\
\text { https://www.youtube.com/watch?v=3ClphZJTWqM\&feature=youtu.be } \\
\text { https://www.youtube.com/watch?v=d-fjVuzmHL0\&feature=youtu.be } \\
\text { https://www.youtube.com/watch?v=hXYMI8zLwG\&\&feature=youtu.be } \\
\text { https://www.youtube.com/watch?v=UydSbEvRkss\&feature=youtu.be } \\
\text { https://www.youtube.com/watch?v=WltcLfuQoA4\&feature=youtu.be } \\
\text { https://www.youtube.com/watch?v=z5BmxYGljpQ\&feature=youtu.be } \\
\text { https://www.youtube.com/watch?v=3ClphZJTWqM\&feature=youtu.be } \\
\text { https://www.youtube.com/watch?v=1unjH5XBurM\&feature=youtu.be } \\
\text { https://www.youtube.com/watch?v=5_qjFFcuyNw\&feature=youtu.be } \\
\text { https://www.youtube.com/watch?v=H5f74ZOh2vY\&feature=youtu.be } \\
\text { https://www.youtube.com/watch?v=Msu-bkk0HLg\&feature=youtu.be } \\
\text { https://www.youtube.com/watch?v=BjW6RPWTfzY\&feature=youtu.be } \\
\text { https://www.youtube.com/watch?v=NtrIfRTx8BE\&feature=youtu.be } \\
\text { https://www.youtube.com/watch?v=Q4IznkekJfA\&feature=youtu.be } \\
\text { https://www.youtube.com/watch?v=yysRGyafjOw\&feature=youtu.be } \\
\text { https://www.youtube.com/watch?v=JtkrxNsDGvw\&feature=youtu.be } \\
\text { https://www.youtube.com/watch?v=OzEZakvwWQE\&feature=youtu.be } \\
\text { https://www.youtube.com/watch?v=LToep_A0y_s }\end{array}$ \\
\hline
\end{tabular}

The review and revision of Sparkol VideoScribebased teaching materials was done completely. According to reviewer related to the suitability of the material presented with the semester learning plan was $100 \%$ strongly relevant (See Figure 2).

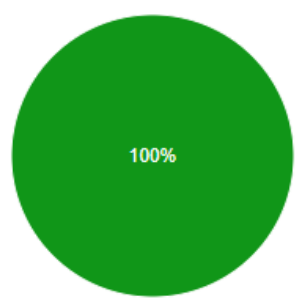

Strongly Irrelevant

Irrelevant

Relevant

Strongly Relevant

Figure 2. Suitability of the content provided in the Semester Learning Plan
Then, the suitability of the content presented was highly applicable to $50 \%$ of the predicted competencies and relevant to $50 \%$ (Figure 3).

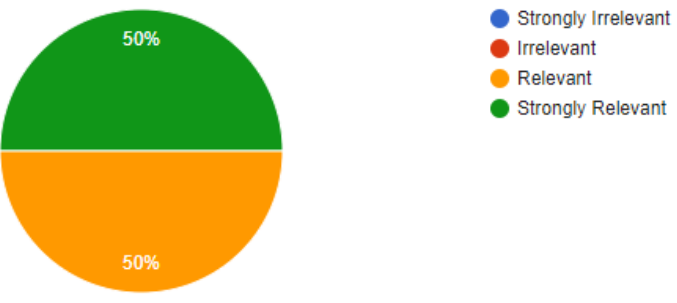

Figure 3. Suitability of the material the expected competencies were addressed 
The suitability of the photos presented for the content being taught was highly relevant to $50 \%$ and relevant to $50 \%$ (See Figure 4).
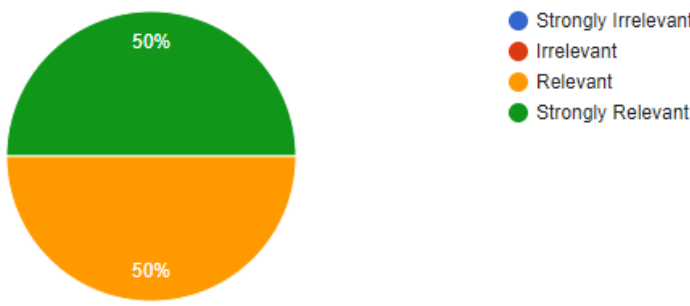

Figure 4. The suitability of the photos displayed with the subject being taught

The suitability of video music and voice accompaniment was $100 \%$ acceptable (Figure 5).

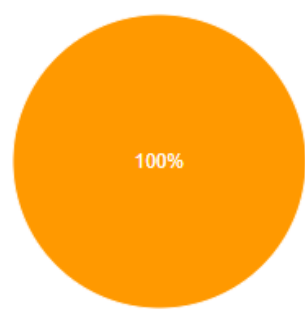

Strongly Irrelevan

Irrelevant

Relevant

Strongly Relevant

Figure 5. Music and Voice Accompaniment Suitability

Videos have been adapted to the needs of students and lecturers in the Digital Age, with the concept of elearning being $50 \%$ highly relevant and $50 \%$ relevant (Figure 6).

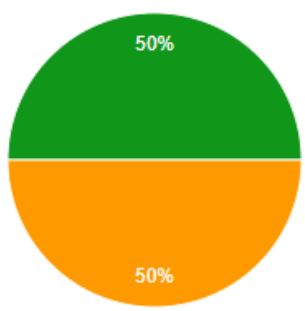

$$
\begin{aligned}
& \text { Strongly Irrelevant } \\
& \text { Irrelevant } \\
& \text { Relevant } \\
& \text { Strongly Relevant }
\end{aligned}
$$

Figure 6. Videos focused on the needs of students and lecturers in the digital age with the idea of elearning

The last, Sparkol Videoscribe based learning is $50 \%$ of highly applicable and 50\% relevant to elearning (Figure 7).

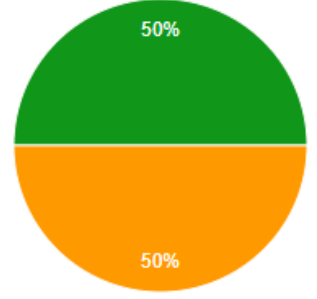

Strongly Irrelevant

Irrelevant

Relevant

Strongly Relevant

Figure 7. Learning based on Sparkol Videoscribe is in line with e-learning

The Study Program as respondents filled the instrument consist of $43.9 \%$ from undergraduate of English Language Education and 56\% from undergraduate of Mathematics Education (Figure 8).

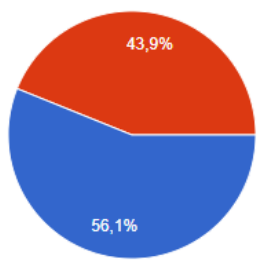

S1 Mathematics Education - S1 English Language Educatio

Figure 8. Study Program of Respondents

The first questionnaire related to Sparkol VideoScribe makes learning easy, and the respondents said $79.3 \%$ agree (Figure 9).

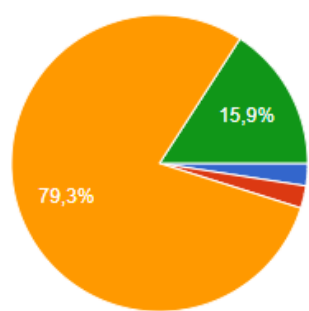

Strongly Disagree

Disagree

Agree

Strongly Agree

Figure 9. Sparkol VideoScribe Makes Learning Easy

The second questionnaire discussed about Sparkol VideoScribe can generate motivation in learning, and the result showed that $72 \%$ agree (Figure 10). 


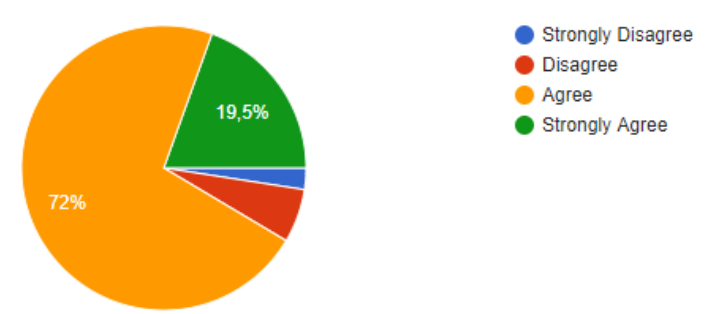

Figure 10. Sparkol VideoScribe Can Generate Motivation in Learning

The third questionnaire related to Sparkol VideoScribe can make learning material clearer, and the result stated that $78 \%$ agree (Figure 11).

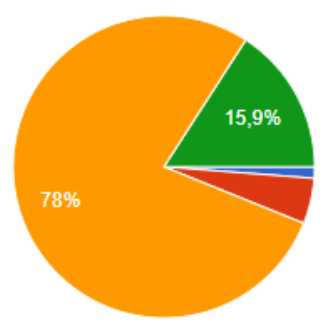

Strongly Disagree

Disagree

Agree

Strongly Agree

Figure 11. Sparkol VideoScribe Can Make

Learning Material Clearer

The fourth questionnaire was about Sparkol VideoScribe can make presentations more attractive, and $61.1 \%$ agree (Figure 12).
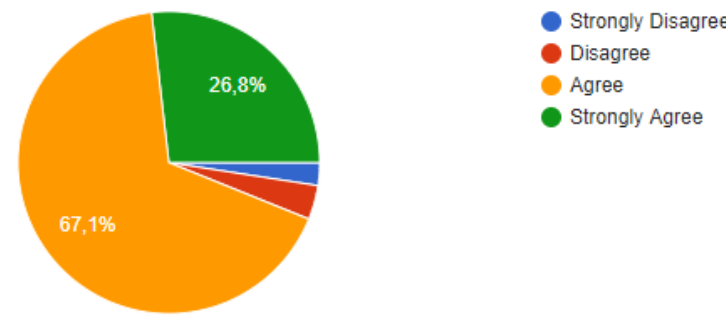

Figure 12. Sparkol VideoScribe Can Make Presentations More Attractive

The fifth questionnaire talked about Sparkol VideoScribe can help lecturers and students use computers in learning, and $74.4 \%$ agree (Figure 13).

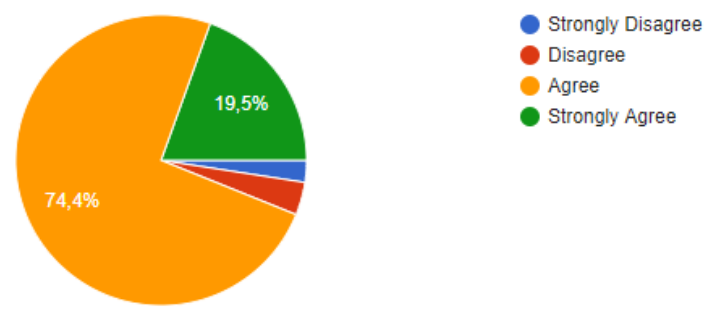

Figure 13. Sparkol Videoscribe Can Help Lecturers and Students Use Computers In Learning

The sixth questionnaire was about Sparkol VideoScribe for instruction is interesting to follow, and $85.4 \%$ agree (Figure 14).

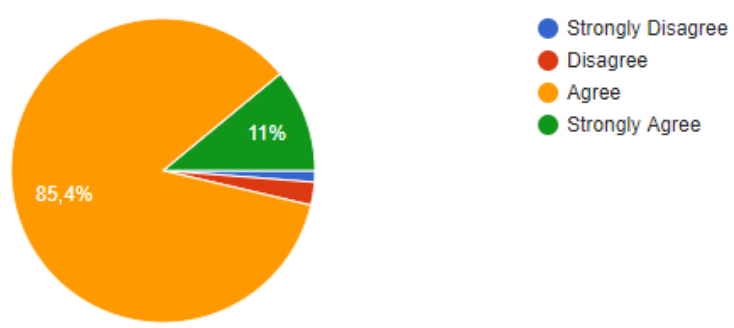

Figure 14. Sparkol VideoScribe for Instruction is Interesting to Follow

The last questionnaire talked about Sparkol VideoScribe for instruction supports information technology-based learning, and $69.5 \%$ agree (Figure $15)$.

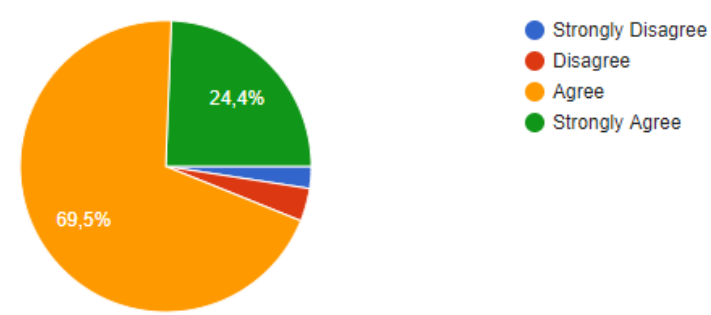

Figure 15. Sparkol Videoscribe for Instruction Supports Information Technology-Based Learning

The result from this paper was supported by Maulina et al [15] the Sparkol Videoscribe has been instrumental in developing students' speaking skills. Rahmatika and Ratnasari [16]; Azizah [17] state that Sparkol Videoscribe bilingual learning media is successful, feasible, and interesting by producing good results in its implementation. According to Sudrajad and Hardinto [18] Sparkol Videoscribe will make it easier for teachers to pass on the knowledge and increase motivation. Wulandari [19] states that sparkol 
videoscribe can be an alternative media that can increase student interest in learning [20].

\section{CONCLUSION}

The urgent need to continue learning and advanced digital technology requires a new approach to changing global circumstances in the age of Industrial Revolution4.0, such as the use of Sparkol Videoscribe on instruction. This paper concluded that sparkol videoscribe can make it easier for teachers to pass on the knowledge and increase motivation and can be an alternative media that can increase student interest in learning.

\section{AUTHORS' CONTRIBUTION}

Muhammad Kristiawan: designed and performed experiments and analysed data. Nur Aminudin: Performed analyses and supervised the research and cowrote the paper.

\section{ACKNOWLEDGMENTS}

We would like to express our special thanks and appreciation to the Rector of the University of Bengkulu and the University of Aisyah Pringsewu, who have assisted us in this wonderful project. This project was funded by a research grant from the University of Bengkulu. Secondly, we would also like to thank our friends at the University of Bengkulu and the University of Aisyah Pringsewu who have supported us a great deal in finalizing this project within a short timeframe.

\section{REFERENCES}

[1] Yusro, M. (2018). Strategi Peningkatan Mutu Akreditasi Sekolah Menengah Kejuruan (SMK) Memasuki Era Revolusi [Strategies for Improving the Quality of Vocational High School (SMK) Accreditation Entering the Revolutionary Era]. 3(peringkat 11), 9-13

[2] Gaspar, M., Julião, J., \& Cruz, M. (2019). Organizational strategies induced by the fourth industrial revolution: Workforce awareness and realignment. Lecture Notes in Electrical Engineering, 330-336. https://doi.org/10.1007/978-3-319-91334-6_45

[3] Prasetyo, B. (2018). Revolusi Industri 4.0 Dan Tantangan Perubahan Sosial. IPTEK Journal of Proceedings Series, O(5), 22-27.

[4] Kristiawan, M., \& Muhaimin, M. (2019). Teachers' Obstacles In Utilizing Information and Communication Technology. International Journal of Educational Review, 1(2), 56-61.
[5] Kristiawan, M., Nizarani., \& Syamsidar. (2019). Role of School on Forming Character of ZGeneration Through Entrepreneurial Skills. International Journal of Scientific \& Technology Research, 8(10).

[6] Kin, T. M., \& Kareem, O. A. (2019). School leaders' Competencies that make a difference in the Era of Education 4.0: A Conceptual Framework. International Journal of Academic Research in Business and Social Sciences, 9(4), 214-225. https://doi.org/10.6007/ijarbss/v9i4/5836

[7] Law of Republic Indonesia Number 5 of 2014.

[8] Acikalin, M. (2010). Exemplary Social Studies Teachers Use of Computer-Supported Instruction in the Classroom. "TOJET: The Turkish Online Journal of Educational Technology. October 2010, volume 9 Issue 4".[9] Ahmad, A., Al-Mashari, A., \& Al-Lawati, A. (2010). On the Development of a Computer Based Diagnostic Assessment Tool to Help in Teaching and Learning Process. "International Journal of Education and Development using Information and Communication Technology (IJEDICT), 2010, Vol. 6, Issue 1, pp. 76-87".

[10] Akpunar, B. (2011). The Effect of Webblog Based Instruction on the Metacognition Levels of Preservice Teachers. "International Journal of Education and Development using Information and Communication Technology (IJEDICT), 2011, Vol. 7, Issue 2, pp. 38-45".

[11] Alias, N., Siraj, S., Daud, M. K. A. Md. \& Hussin, Z. (2013). Effectiveness of Facebook Based Learning to Enhance Creativity Among Islamic Studies Students by Employing Isman Instructional Design Model. "TOJET: The Turkish Online Journal of Educational Technology. January 2013, volume 12 Issue 1"

[12] Andoh, C. B. (2012). Factors Influencing Teachers' Adoption and Integration of Information and Communication Technology into Teaching: A Review of the Literature. "International Journal of Education and Development using Information and Communication Technology (IJEDICT), 2012, Vol. 8, Issue 1, pp. 136-155".

[13] Kristiawan, M. (2014). A Model for Upgrading Teachers Competence on Operating Computer as Assistant of Instruction. Global Journal of HumanSocial Science Research.

[14] Risdianto, E. Darmawan, A., Kristiawan, M., Wachidi., \& Riyanto. (2020). Rasch Model Analysis on the Feasibility Test of Basic Physics II 
Practical Guide using Augmented Reality. ARPN Journal of Engineering and Applied Sciences, 15(4): 482-490

[15] Maulina, U., Hikmah, S., \& Pahamzah, J. (2019). Attractive Learning Media to Cope with Students' Speaking Skills in the Industry 4.0 Using Sparkol Videoscribe. Online Submission, 2(5), 132-140.

[16] Rahmatika, D. F., \& Ratnasari, N. (2018). Media Pembelajaran Matematika Bilingual Berbasis Sparkol Videoscribe [Bilingual Mathematics Learning Media Based on Videoscribe Sparkol]. Desimal: Jurnal Matematika, 1(3), 385393.

[17] Azizah, A. N. (2018). Pengembangan media pembelajaran sparkol videoscribe dalam meningkatkan minat belajar siswa pada mata pelajaran ekonomi materi perdagangan internasional di sma batik 2 surakarta [The development of sparkol videoscribe learning media in increasing students' interest in learning in economic subjects on international trade material at SMA Batik 2, Surakarta] (Doctoral dissertation, Universitas Muhammadiyah Surakarta).
[18] Sudrajad, F. B., \& Hardinto, P. (2018). The Application Teams Games Tournaments and Media Learning Sparkol Video Scribe to Increase Motivation and Study Results. Classroom Action Research Journal (CARJO), 1(3), 125-132.

[19] Wulandari, D. A. (2016). Pengembangan Media Pembelajaran Menggunakan Sparkol Videoscribe dalam Meningkatkan Minat Belajar Siswa pada Mata Pelajaran IPA Materi Cahaya Kelas VIII di SMP Negeri 01 Kerjo Tahun Ajaran 2015/2016 [Learning Media Development Using Sparkol Videoscribe in Increasing Student Learning Interest in Science Subjects in Class VIII Light Material at SMP Negeri 01 Kerjo Academic Year 2015/2016] (Doctoral dissertation, Universitas Negeri Semarang).

[20] Maseleno, A., Ayshwary, B., Ivanova, T. N., Hashim, W., Nguyen, P. T., Shankar, K., Kristiawan, M., Huda, M. (2019). General Theoretical and Philosophical Aspects of Modern Education. Aspectos Teóricos y Filosóficos Generales de la Educación Moderna. Revista San Gregorio 2019, No. 32 Special Issues August. 